\title{
Self-efficacy, job satisfaction, motivation and commitment: exploring the relationships between indicators of teachers' professional identity
}

\author{
Esther T. Canrinus • Michelle Helms-Lorenz • \\ Douwe Beijaard • Jaap Buitink • Adriaan Hofman
}

Received: 16 June 2010 / Revised: 16 June 2011 / Accepted: 27 June 2011 /Published online: 14 July 2011

(C) The Author(s) 2011. This article is published with open access at Springerlink.com

\begin{abstract}
This study investigates how relevant indicators of teachers' sense of their professional identity (job satisfaction, occupational commitment, self-efficacy and change in level of motivation) are related. A model is proposed, tested with structural equation modelling (SEM) and refined using data from 1,214 Dutch teachers working in secondary education. Classroom self-efficacy and relationship satisfaction play a key influencing role in the relationships between the indicators. Using multiple-group SEM, the parameters of the overall model are similar for the novice, experienced and senior teachers in a constrained model. This aspect of similarity across experience groups is in line with findings of previous research on teachers' professional identity. The present study contributes to the further development of a solid theory on teachers' professional identity, which has been lacking.
\end{abstract}

Keywords Professional identity · Teaching - Identification · Teaching experience

The concept of 'professional identity' has recently attracted interest in various fields, such as in the medical field (e.g. Pratt et al. 2006) and in the field of the legal profession (e.g.

E. T. Canrinus $(\bowtie) \cdot$ M. Helms-Lorenz $\cdot$ J. Buitink $\cdot$ A. Hofman

University Centre for Learning \& Teaching, University of Groningen, Landleven 1, 9747 AD

Groningen, the Netherlands

e-mail: e.t.canrinus@rug.nl

M. Helms-Lorenz

e-mail: m.helms-lorenz@rug.nl

J. Buitink

e-mail: j.buitink@rug.nl

A. Hofman

e-mail: w.h.a.hofman@rug.nl

D. Beijaard

Eindhoven University of Technology, P.O. Box 513, 5600 MB Eindhoven, the Netherlands

D. Beijaard

e-mail: d.beijaard@tue.nl 
Mather et al. 2001). Most research has been performed within the field of teaching and teacher education (see for a review Beijaard et al. 2004). Research on teachers' sense of their professional identity has mainly focussed on what affects - the development ofteachers' professional identity (e.g. Hamman et al. 2010). To a lesser extent, more outcomeoriented studies exist. Moore and Hofman (1988), for example, found a strong professional identity to be related to a more pronounced critical stance towards working conditions. Additionally, Nias (1997) and Day (2002) claim, based on deductive reasoning and their personal theories, that professional identity is related to how teachers respond to educational reforms.

An extensive research on teachers' professional identity in relation to teacher effectiveness was performed in the VITAE Study (Day et al. 2006). In this 4-year longitudinal project, the key aim was to investigate factors contributing to variations in teachers' effectiveness. Day et al. (2006) state that by the different ways in which teachers balance three relevant dimensions in their work (a personal dimension (life outside the school), a professional dimension (social and policy expectations of what a good teacher is) and a situational dimension (the direct working environment of the teacher)), different professional identities emerge. The results of the VITAE Study showed that this balancing of dimensions is one of the factors contributing to teacher effectiveness (measured by valueadded measures of pupils' progress and attainment).

Professional identity pertains to how teachers see themselves as teachers based on their interpretations of their continuing interaction with their context (Kelchtermans 2009). It is argued here that this interaction manifests itself in teachers' job satisfaction, occupational commitment, self-efficacy and change in level of motivation. According to Day (2002), teachers' sense of their professional identity coincides with these constructs. A similar conclusion was drawn by Puurula and Löfström (2003) in their study on the development of professional identity of employees in small- and medium-sized enterprises. Teachers' job satisfaction, occupational commitment, self-efficacy and change in level of motivation are often described in the literature as being important to teacher behaviour (cf. Ashton and Webb 1986; Firestone 1996; Toh et al. 2006; Watt and Richardson 2008), and they represent a personal perspective on how teachers view themselves as professionals in their work.

Kelchtermans $(2005,2009)$ uses the term 'self-understanding' for a process closely related to professional identity. According to Kelchtermans (2009), five components make up this self-understanding: teachers' self-image, self-esteem, job motivation, task perception and future perspective. Kelchtermans' definitions of teachers' self-image and self-esteem closely relate to teachers' self-efficacy, which is perceived here as an indicator of teachers' sense of their professional identity. In line with Kelchtermans, we believe teachers' motivation to be relevant for teachers' sense of their professional identity. Nevertheless, teachers' task perception is defined by Kelchtermans (2009) as teachers' core values and ideas of what it means to be a teacher. This definition relates to Nias' (1996) perspective on the relevance of teachers' values for their identity. We do agree that such values are relevant, yet, we believe this to be mainly a personal aspect developed during one's personal upbringing and development and do not include this construct in this study. Here, we focus on constructs currently under influence of both the person and the context in which the teacher works. Therefore, similar to the concept of teachers' task perception, the concept of teachers' future perspective is not incorporated in our theory on teachers' sense of their professional identity. This study investigates the teachers' perceptions of their present professional identity in their present work environment.

In our view, an indication of teachers' sense of their professional identity is acquired through investigating teachers' self-efficacy, job satisfaction, motivation and occupational 
commitment in their combination. How these constructs are related to each other and how much weight is assigned to them by teachers is unclear. Clarifying this is the main aim of this study. To understand the relationships between the constructs, a conceptual model based on the literature will first be postulated and subsequently tested empirically. A solid theory of teachers' sense of their professional identity is not available for the construction of this model. The model presented is based on separate studies that investigate only parts of the proposed model. Through the present exploratory study, we aim to contribute to such a solid, more comprehensive theory to understand teachers' sense of their professional identity.

Generally, it is stated that professional identity is dynamic (e.g. Beijaard et al. 2004). Sugrue (2005) elaborates on this and argues that identity is not distinctly individual and unalterable. People may strive to maintain their habits and routines, but are not immune to outside influences (Sugrue 2005). Teachers obtain more and more experience, and more and different influences affect teachers as teachers have worked longer in their profession. Ibarra (1999) poses that people use trial versions of their professional identity before assuming a fully elaborated professional identity. In their longitudinal study, Dobrow and Higgins (2005) found the clarity of 136 (former) MBA students' professional identity to increase over time. Based on these studies, we can assume that teachers' sense of their professional identity is dynamic. As teachers' self-efficacy, job satisfaction, motivation and occupational commitment are perceived here as indicators of teachers' sense of their professional identity, teachers' ratings of these indicators may be dynamic as well.

It remains unclear whether the relationships between these indicators will also be dynamic and subject to change. Therefore, in addition to the main research question of this study and in a first step to further understand the dynamics of teachers' sense of their professional identity, the model will be applied to data from teachers with different levels of experience in order to explore whether the relationships between the constructs are linked to experience. Research focussing on the retention of novice teachers uses respondents with 3 to 5 years of teaching experience (e.g. Ingersoll and Smith 2004). Therefore, the cutoff point for an exact definition of noviceness was taken to be the first 5 years of work experience in education. Super and Hall (1978) presented a figure representing the stages in career development. In that figure, employees up to the age of 45 are said to be advancing and establishing their careers. In the case of Dutch teachers, this means that they have approximately 15 years of experience before having fully established their careers. Therefore, senior teachers are perceived to be those teachers who have worked in education for 15 years or more. The teachers with experience in between the novice and senior teachers, the experienced teachers, have 6 to 14 years of experience in education. Comparing these three groups may result in insight into the stable and/or dynamic aspects of the sense teachers have of their professional identity throughout their careers.

\section{Conceptual framework}

Job satisfaction, self-efficacy, occupational commitment and change in teachers' level of motivation are put forward here as indicators of teachers' sense of their professional identity. They are the representation of the more tacit construct that professional identity appears to be. Therefore, it is important to understand how these constructs relate to each other. They have been investigated separately and in diverse combinations in various studies (e.g. Cooper-Hakim and Viswesvaran 2005), but no research has been done which relates them all to one another nor to provide, as argued in this study, an impression of teachers' perceptions of their own professional identity. 
From the literature, we derived assumptions regarding the relationships between the indicators of teachers' sense of their professional identity. First, studies using structural equation modelling (SEM) were selected for this purpose. Second-or where the former studies were unavailable - studies using regression analyses were selected. Third, where none of the other two types of study were available for the relationships to be specified, studies reporting correlations were selected. In the next section, we elaborate upon the studies used to formulate the following assumptions:

1. Teachers' self-efficacy contributes to teachers'
a. change in level of motivation
b. job satisfaction
c. occupational commitment

2. Teachers' job satisfaction contributes to teachers'
a. change in level of motivation
b. occupational commitment

3. Teachers' change in level of motivation contributes to teachers' occupational commitment.

\section{Self-efficacy}

In various theories, self-efficacy is put forward as a determining behaviour. The expectancy value theory (Vroom 1964; Wigfield and Eccles 2000), for instance, assumes that the likelihood of attaining a valued outcome leads to specific behaviour. If a person believes that $\mathrm{s} / \mathrm{he}$ is capable of gaining a positive result, it will be more likely that $\mathrm{s} /$ he repeats that behaviour. Likewise, within the attribution theory, the beliefs of responsibility for specific outcomes are put forward as guiding a person's subsequent behaviour (Weiner 1972). Therefore, teachers' self-efficacy was taken as the starting point for the construction of our conceptual model.

Bandura (1977) distinguished outcome expectations and efficacy expectations. In current definitions of teacher self-efficacy, some authors focus on teachers' perceived ability to affect student outcomes (e.g. De la Torre Cruz and Casanova Arias 2007), whilst others focus exclusively on efficacy expectations but extend this by considering the contexts in which teachers work (e.g. Tschannen-Moran et al. 1998). As Friedman and Kass' (2002) definition takes into account the classroom context and the broader school context, as well as relational aspects-which play an important role in the work of teachers - their definition of teacher self-efficacy is followed in this study:

A teacher's perception of his or her ability to (a) perform required professional tasks and to regulate relations involved in the process of teaching and educating students and (b) perform organizational tasks, become part of the organization and its political and social processes. (Friedman and Kass 2002, p. 684)

Within Ryan and Deci's (2000) self-determination theory, a person's feeling of competence is related to a person's level of intrinsic motivation. Bandura (1993) himself refers to self-efficacy beliefs as playing a key role in motivational processes. Self-efficacy is often described as being a component of motivation and has been used in some studies as a measurement for the motivation construct (cf. Ciani et al. 2008). Self-efficacy is related to behavioural changes, often through its effect on motivation. Schepers et al. (2005), for 
instance, describe teachers' professional efficacy as being the primary motivator in teachers' work. Therefore, we believe that teachers' self-efficacy contributes positively to teachers' change in level of motivation.

Using an online instrument, Judge et al. (2005) surveyed 251 employees working in three different organisations and expected a positive relationship between these employees' core self-evaluations. These are the fundamental assessments that people make about their worthiness, competence, and capabilities and include self-efficacy and job satisfaction. SEM analysis revealed a significant relationship $(\beta=0.47, p<0.01)$ between the employees' self-efficacy as part of their core self-evaluations and satisfaction with their jobs. Like Judge et al. (2005), Caprara et al. (2006) used SEM for their studies. They found a positive and significant relationship $(\beta=0.74, p<0.05)$ between teachers' self-efficacy and job satisfaction of 75 junior high school teachers. In line with these studies, we assume that teachers' self-efficacy contributes to teachers' job satisfaction.

Rots et al. (2007) considered data of 209 teachers from Belgium who had graduated between 2001 and 2003. By using SEM, Rots et al. (2007) found "[...] that teaching commitment was positively and directly related to teacher efficacy $(\beta=0.29, \mathrm{p}<0.01)[\ldots]$ " (p. 550). Likewise, Chan et al. (2008) used SEM on data from 2,130 primary school teachers and 1,587 secondary school teachers in Singapore. A positive relationship was found between teachers' self-efficacy and commitment in both groups $(\beta=0.26$ and $\beta=0.22$, CR $>2.0$, respectively). The definition of commitment of Rots et al. (2007) and Chan et al. (2008) is in line with the definition for the occupational commitment construct used here: "a psychological link between a person and his or her occupation that is based on an affective reaction to that occupation" (Lee et al. 2000, p. 800). Against this background, we assume that teachers' self-efficacy contributes to teachers' occupational commitment.

Guay et al. (2010) examined, based on the self-determination theory, the longitudinal relations between academic self-concept, autonomous academic motivation and achievement. Using SEM on data of 925 (T1) and 828 (T2) high school students, they concluded that autonomous academic motivation mediates the relation between academic self-concept and academic achievement. Guay et al. (2010) state that perceived competence is a construct akin to self-concept and used a perceived competence scale to measure academic self-concept. We believe that self-efficacy, likewise, is similar to these constructs and therefore use the findings of Guay et al. as an indication that motivation may play a mediating role in the effect of self-efficacy on other constructs. To investigate this claim, we assume in the conceptual model that the effect of self-efficacy on occupational commitment is partially mediated by a change in teachers' level of motivation.

\section{Job satisfaction}

Bogler and Somech (2004) suggest further research into the effect of various variables on teachers' commitment, such as teachers' job satisfaction. Using SEM, Landsman (2001) investigated the hypothesis that job satisfaction positively affects occupational commitment using data from 1,133 public child welfare employees. The employees' job satisfaction significantly predicted the employees' occupational commitment $(\beta=0.21, p<0.001)$. Therefore, we assume that teachers' job satisfaction contributes to teachers' occupational commitment.

Through correlation analysis, teachers' motivation has been found to be significantly related to teachers' job satisfaction $(r=0.38, p<0.01$; Davis and Wilson 2000). A specific direction between these two constructs has been suggested by, for instance, Maslow. Maslow (1943) developed his theory on persons' needs, in which he explains that 
fulfilment of these needs motivates people. Hackman and Oldham (1976) confirmed their job characteristics model using multiple regression analysis on the data of 658 employees working on 62 different jobs in seven organisations. The model specifies the conditions under which employees will become internally motivated to perform their work effectively. Five core job dimensions (skill variety, task identity, task significance, autonomy and feedback) influence three critical psychological states (experienced meaningfulness, experienced responsibility for outcomes and knowledge of the actual results) which influence personal and work outcomes including work motivation. Therefore, we assume that teachers' job satisfaction contributes to teachers' change in their level of motivation.

\section{Change in level of motivation and occupational commitment}

Motivation is defined as a set of interrelated beliefs and emotions. These beliefs and emotions drive and influence behaviour (Martin and Dowson 2009; Wentzel 1999). Several authors further specified the influence of motivation on behaviour: motivation is what starts, sustains and concentrates behaviour (e.g. Sinclair et al. 2006). Latham and Pinder (2005) refined the definition of motivation further for the concept of work motivation. They defined work motivation as "a set of energetic forces that originate both within as well as beyond an individual's being, to initiate work-related behaviour and to determine its form, direction, intensity and duration" (Latham and Pinder 2005, p. 486). Motivation for teaching is investigated mainly by questioning teachers about varying types of motivation (e.g. Watt and Richardson 2008), for instance: 'working with children' or 'have had inspiring teachers'.

Here, the focus lies on teachers' change of level of motivation. We do not investigate what made the teachers choose the teaching profession in the first place, yet we are interested in their present level of their motivation in relation to their level of motivation when they entered the teaching profession. More precisely, we are interested in how this level of motivation changes due to the interaction between person and context. We are convinced that the change in level of motivation portrays more information than the level of motivation when teachers entered the teaching profession or the current level of teachers' motivation portray separately. We hypothesise that a change in level of motivation is important for teachers' present sense of their professional identity as it incorporates previous experiences.

No research was found that directly relates an overall measure of teachers' - change inlevel of motivation to teachers' occupational commitment. Sinclair et al. (2006) have speculated that teachers' motivation underpins teachers' occupational commitment, but did not investigate this proposition further. For the purpose of our study, we specify that change in teachers' level of motivation contributes positively to teachers' occupational commitment and investigate whether this relationship is actually present. Thus, we assume that an increase in teachers' level of motivation will lead to more occupational commitment and that a decrease in teachers' level of motivation will lead to less occupational commitment.

\section{Method}

Participants

To test the proposed model, an online questionnaire was distributed to 5,575 Dutch teachers working in secondary education. These teachers received an e-mail invitation to participate. 
The teachers' e-mail addresses were retrieved from the web sites of their schools. The survey was personalized by inserting a link into each participant's e-mail which permitted access to the questionnaire. Teachers who did not respond or who only partially completed the instrument were sent a reminder e-mail after 2 weeks.

Of the 5,575 teachers approached, 1,214 (21.8\%) returned a completed questionnaire. The distribution of male and female respondents was $52.9 \%$ and $45.2 \%$, respectively; 23 teachers did not indicate their gender. The average age was $44(\mathrm{SD}=11.1)$ and the average amount of experience in education was 17 years $(\mathrm{SD}=11.6)$. This is an accurate representation of the population of Dutch teachers working in secondary education (Dutch Ministry of Education, Culture, and Science, 2007).

For the second aim of this study, to explore whether the relationships between the constructs are linked to experience, the participating teachers were divided into three groups based on their level of experience: 265 novice teachers, 341 experienced teachers and 603 senior teachers.

\section{Data preparation}

A survey to measure the constructs relevant for teachers' sense of their professional identityteachers' job satisfaction, self-efficacy, occupational commitment and change in level of motivation - was developed. Change in teachers' level of motivation was determined by subtracting teachers' score on the question "How motivated were you when you started teaching?" from teachers' score on the question "How motivated are you currently?" Table 1 summarizes the relevant instruments used to measure teachers' job satisfaction, self-efficacy and occupational commitment.

The items measuring job satisfaction, self-efficacy and occupational commitment were submitted to a principal component analysis (PCA) because the instruments used to measure these constructs had not yet been used together in previous research. To reduce the confounding of constructs, we conducted a PCA to purify the latent variables. The variable measuring the change in teachers' level of motivation was excluded from the PCA as it was measured by one calculated item.

Based on the PCA, job satisfaction, measured on a five-point Likert scale, was split into teachers' relationship satisfaction (containing items on co-workers, support and autonomy ${ }^{1}$ ) and teachers' satisfaction with their salary (containing items on salary and fringe benefits). The indicator 'relationship satisfaction' furthermore contained self-efficacy items on teachers' relationship with school administrators, measured on a six-point Likert scale. Teachers' classroom self-efficacy was found to be a separate indicator. Occupational commitment, measured on a seven-point Likert scale, was split into teachers' affective occupational commitment (referring to positive emotions towards the occupation) and responsibility to remain in teaching (referring to the sense of obligation to remain in the occupation and the awareness of the costs associated with leaving the occupation). The factor affective occupational commitment furthermore contained job satisfaction items measuring satisfaction with work itself (e.g. "I like the work I do a lot"). The internal consistencies of the indicators of teachers' sense of their professional identity ranged from 0.81 (satisfaction with salary) to 0.92 (classroom self-efficacy). Table 2 gives an overview of the features of the final factors.

\footnotetext{
${ }^{1}$ It may appear strange that items on autonomy were part of the 'relationship satisfaction' factor. Nevertheless, these items refer to the freedom teachers feel related to others, for instance: 'I am not closely watched during my work' or 'I am given a large amount of freedom in my work'. These items are an indication of the absence of interference by other people.
} 
Table 1 Questionnaires used to investigate teachers' job satisfaction, occupational commitment and selfefficacy

\begin{tabular}{|c|c|c|c|c|}
\hline Content & $\begin{array}{l}\text { Questionnaire } \\
\text { and authors }\end{array}$ & $\begin{array}{l}\text { Original } \\
\text { subscales }\end{array}$ & $\begin{array}{l}\text { Original no. } \\
\text { of items }\end{array}$ & $\begin{array}{l}\text { Example } \\
\text { item }\end{array}$ \\
\hline & & & & $\begin{array}{l}\text { To what extent do you agree } \\
\text { with the statement: }\end{array}$ \\
\hline \multirow[t]{6}{*}{$\begin{array}{l}\text { Job } \\
\text { satisfaction }\end{array}$} & \multirow[t]{6}{*}{$\begin{array}{l}\text { Job satisfaction index } \\
\text { (ASI) Van der Ploeg } \\
\text { and Scholte (2003) }\end{array}$} & Support & 6 & $\begin{array}{l}\text {-Where I work, I am not } \\
\text { getting enough support. }^{\text {a }}\end{array}$ \\
\hline & & Autonomy & 6 & $\begin{array}{l}\text {-I am given a large amount } \\
\text { of freedom in the work I do. }\end{array}$ \\
\hline & & Relationships & 6 & $\begin{array}{l}\text {-The other members of the } \\
\text { team inspire me. }\end{array}$ \\
\hline & & Work & 6 & -I like the work I do a lot. \\
\hline & & Fringe benefits & 6 & $\begin{array}{l}\text {-My salary matches my } \\
\text { education and skills. }\end{array}$ \\
\hline & & & & $\begin{array}{l}\text { To what extent do you } \\
\text { agree with the statement: }\end{array}$ \\
\hline \multirow[t]{4}{*}{$\begin{array}{l}\text { Occupational } \\
\text { commitment }\end{array}$} & \multirow[t]{4}{*}{$\begin{array}{l}\text { Based on Meyer } \\
\text { et al. (1993) }\end{array}$} & Affective $^{\mathrm{b}}$ & 6 & $\begin{array}{l}\text {-I'm proud to be in the } \\
\text { teaching profession. }\end{array}$ \\
\hline & & Continuance $^{\mathrm{b}}$ & 6 & $\begin{array}{l}\text {-It would be costly for me to } \\
\text { change my profession now. }\end{array}$ \\
\hline & & Normative $^{\mathrm{b}}$ & 6 & $\begin{array}{l}\text {-I do not feel any obligation } \\
\text { to remain in the } \\
\text { teaching profession }\end{array}$ \\
\hline & & & & $\begin{array}{l}\text { To what extent do you agree } \\
\text { with the statement: }\end{array}$ \\
\hline \multirow[t]{2}{*}{ Self-efficacy } & \multirow{2}{*}{$\begin{array}{l}\text { Classroom and school } \\
\text { context teacher self- } \\
\text { efficacy scale (CSC } \\
\text { teacher self-efficacy } \\
\text { scale); Friedman and } \\
\text { Kass (2002) }\end{array}$} & Classroom context & 19 & $\begin{array}{l}\text {-I think I can be very creative } \\
\text { in my work with students }\end{array}$ \\
\hline & & School context & 14 & $\begin{array}{l}\text {-I have difficulty making } \\
\text { demands of the school } \\
\text { administration }^{\text {a }}\end{array}$ \\
\hline
\end{tabular}

\footnotetext{
${ }^{\mathrm{a}}$ Item is reversed scored

${ }^{\mathrm{b}}$ Affective commitment refers to the positive emotions towards the profession, normative commitment refers to the sense of obligation to remain in the occupation, and continuance commitment refers to the awareness of the costs associated with leaving the occupation (Meyer et al. 1993)
}

Data analysis

Some of the final factors contained items with differing Likert scales. The factor 'relationship satisfaction', for instance, contained job satisfaction items measured on a five-point Likert scale, as well as self-efficacy items on the relationship with school administrators measured on a six-point Likert scale. Therefore, all item scores were standardised and, subsequently, each participant's mean score was calculated for each factor. These scores were used in further analyses.

Structural equation modelling, using the statistical package LISREL, tested the assumptions proposed in the theory section. Because more factors were found in the 
Table 2 Factor structure of the items used to measure job satisfaction, self-efficacy and occupational commitment

\begin{tabular}{|c|c|c|c|c|c|}
\hline Factor & Factor name & Content & $\begin{array}{l}\text { No. of } \\
\text { items }\end{array}$ & Alpha & $\begin{array}{l}\% \\
\text { explained } \\
\text { variance }\end{array}$ \\
\hline 1 & $\begin{array}{l}\text { Relationship } \\
\text { satisfaction }\end{array}$ & $\begin{array}{l}\text { Self-efficacy and job satisfaction items regarding } \\
\text { the relationship with school administrators and } \\
\text { job satisfaction items on relationships, autonomy } \\
\text { and support }\end{array}$ & 22 & 0.89 & 15.7 \\
\hline 2 & $\begin{array}{l}\text { Classroom self- } \\
\text { efficacy }\end{array}$ & Self-efficacy items on classroom practice & 21 & 0.92 & 10.1 \\
\hline 3 & $\begin{array}{l}\text { Responsibility to } \\
\text { remain in } \\
\text { teaching }\end{array}$ & $\begin{array}{l}\text { A mix of normative }{ }^{\mathrm{a}} \text { and continuance }{ }^{\mathrm{a}} \\
\text { occupational commitment items }\end{array}$ & 12 & 0.80 & 5.9 \\
\hline 4 & Salary satisfaction & Job satisfaction items on salary and fringe benefits & 6 & 0.81 & 3.8 \\
\hline 5 & $\begin{array}{l}\text { Affective } \\
\text { occupational } \\
\text { commitment }\end{array}$ & $\begin{array}{l}\text { A mix of affective occupational commitment items } \\
\text { and job satisfaction items on work }\end{array}$ & 10 & 0.83 & 3.6 \\
\hline Total & & & 71 & 0.88 & 39.1 \\
\hline
\end{tabular}

a Normative commitment refers to the sense of obligation to remain in the occupation and continuance
commitment refers to the awareness of the costs associated with leaving the occupation (Meyer et al. 1993)

PCA than constructs were presented in the theory section, the aforementioned assumptions were adjusted, resulting in the final model presented in Fig. 1. The bases for these adjustments are presented below.

A relationship between classroom self-efficacy and responsibility to remain in teaching was not specified in the model. In our view, classroom self-efficacy relates to a teacher's personal feelings of competence, whereas responsibility to remain in teaching is based more on beliefs about costs and pressures which make a teacher stay in the profession. Likewise, a change in teachers' level of motivation was assumed not to contribute to the occupational commitment factor 'responsibility to remain in teaching'. We believe that the more internal process of change in one's level of motivation will not influence the feelings of responsibility to remain in teaching as these are dependent on more external factors like

Fig. 1 Extended conceptual model

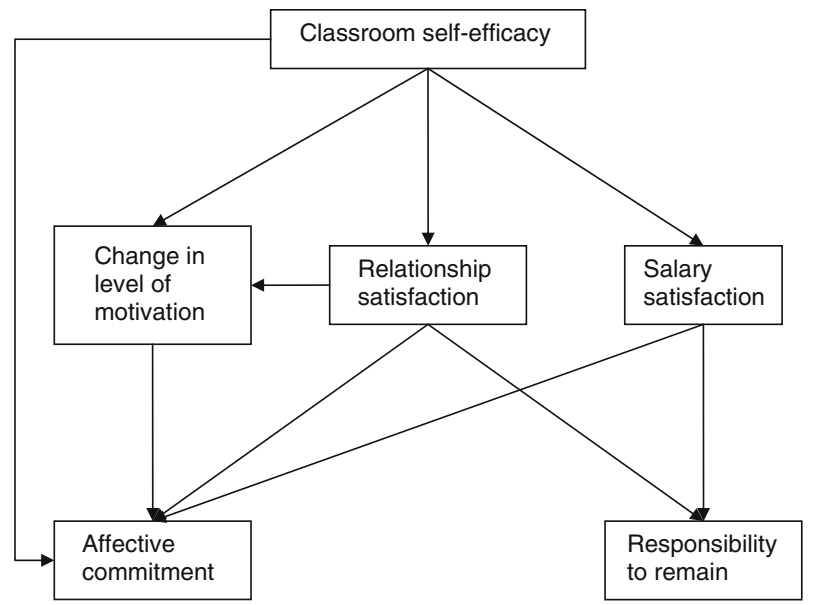


the costs of leaving the profession. Lastly, no relationship was specified between teachers' salary satisfaction and teachers' change in level of motivation based on the findings of Cameron and Pierce (1994) and McKinney (2000) who did not find a relationship between these constructs.

The relationship between teachers' salary satisfaction and their occupational commitment and between teachers' relationship satisfaction and their occupational commitment remains unclear in the literature (see for instance Firestone and Pennell 1993; Liu and Ramsey 2008). Therefore, the relationships between these two satisfaction factors and both factors of occupational commitment are specified in the model to investigate whether these relationships are actually present.

Besides contributing to teachers' occupational commitment, 'relationship satisfaction' is specified to contribute to a change in level of motivation as well. Ryan and Deci (2000) state within their self-determination theory that feelings of relatedness and autonomy, both represented within the factor 'relationship satisfaction', contribute to intrinsic motivation. Therefore, this contribution was specified in the model.

Multiple-group SEM was used to investigate whether the relationships between the constructs are linked to experience. A fully constrained model (invariance model), based on the parameters found in the final model for the total group, was compared with a fully unconstrained model. A $\chi^{2}$ difference test was used to compare the models through testing whether the change in $\chi^{2}$ compared with the change in the degrees of freedom was significant. If the fit of the constrained model would be considerably worse than the fit of the unconstrained model, as indicated by a significant $\chi^{2}$ difference, the parameters would not be considered equal across the groups (Kline 2005). For the multiple-group SEM, the total sample was split into novice, experienced and senior teachers.

\section{Results}

The standard deviation and the correlations between the factor scores-including the constructed motivation variable - are presented in Table 3 .

Teachers' classroom self-efficacy was significantly $(p<0.01)$ related to teachers' relationship satisfaction, affective occupational commitment and change in level of teachers' motivation. Relationship satisfaction and satisfaction with salary were both significantly $(p<0.01)$ related to affective occupational commitment as well as to each other. The factor responsibility to remain in teaching was solely related $(p<0.01)$ to the factor affective occupational commitment. The strongest significant relationship was found between relationship satisfaction and affective occupational commitment $(r=0.57, p<0.01)$.

Table 3 Standard deviation and correlations between factor scores $(N=1,214)$

\begin{tabular}{|c|c|c|c|c|c|c|c|}
\hline Variable & SD & 1 & 2 & 3 & 4 & 5 & 6 \\
\hline 1. Relationship satisfaction & 0.55 & - & & & & & \\
\hline 2. Satisfaction with salary & 0.71 & $0.26^{*}$ & - & & & & \\
\hline 3. Responsibility to remain in teaching & 0.58 & -0.05 & 0.03 & - & & & \\
\hline 4. Affective occupational commitment & 0.62 & $0.57^{*}$ & $0.22 *$ & $0.12 *$ & - & & \\
\hline 5. Change in level of motivation & 1.00 & $0.30 *$ & $0.11 *$ & 0.01 & $0.40^{*}$ & - & \\
\hline 6. Classroom self-efficacy & 0.62 & $0.21 *$ & $-0.11^{*}$ & -0.04 & $0.26^{*}$ & $0.15^{*}$ & - \\
\hline
\end{tabular}

$* p<0.01$ (two-tailed) 
The fit of the proposed model, shown in Fig. 2, was measured by means of $\chi^{2}$, the comparative fit index (CFI), the non-normed fit index (NNFI) and the root mean square error of approximation (RMSEA). The results for the proposed model showed an unsatisfactory fit with the data: $\chi^{2}(5,1,214)=144.08, p<0.01 ; \mathrm{CFI}=0.86 ; \mathrm{NNFI}=0.58$; RMSEA $=0.15$. To improve the model, the non-significant relationship between satisfaction with salary and responsibility to remain in teaching was removed from the model. Furthermore, the relationship between affective occupational commitment and responsibility to remain in teaching was added, in line with findings of McAulay et al. (2006). They found affective professional commitment to be positively associated with normative professional commitment. Additionally, we expected the relationship satisfaction factor to contribute to the 'salary' factor. Firestone and Pennell (1993) found that competitive aspects of differential incentive programmes for teachers have detrimental effects on teachers' commitment to their work. We assume that with a positive perspective towards relationships with colleagues and school administration and a positive perspective on being listened to by the school board, a teacher will feel more satisfied about his/her salary as less competition and feelings of arguments will exist.

Figure 2 represents the final model showing the standardised coefficients of the relationships. This final model was found to have good fit indices: $\chi^{2}(4,1,214)=9.55, p>$ 0.01; $\mathrm{CFI}=0.99$; $\mathrm{NNFI}=0.98$; $\mathrm{RMSEA}=0.03$ with a significant decrease of $\chi^{2}\left(\chi^{2}\right.$ difference $=135.53, p<0.01$ ). Table 4 presents the significant direct, indirect and total effects between the factors in the final model.

The direct effect of teachers' satisfaction with their relationships on teachers' change in level of motivation $(\beta=0.69)$ was the strongest effect found in the final model. The second strongest direct effect was the effect of teachers' relationship satisfaction on teachers' affective occupational commitment $(\beta=0.51)$. The least strong, but still significant $(p<$ 0.01 ), direct effect was present from salary satisfaction to affective occupational commitment $(\beta=0.08)$. A negative direct effect was found from classroom self-efficacy to salary satisfaction $(\beta=-0.20)$ and relationship satisfaction to responsibility to remain in teaching $(\beta=-0.18)$. This indicates that the higher a teacher's self-efficacy, the less satisfied

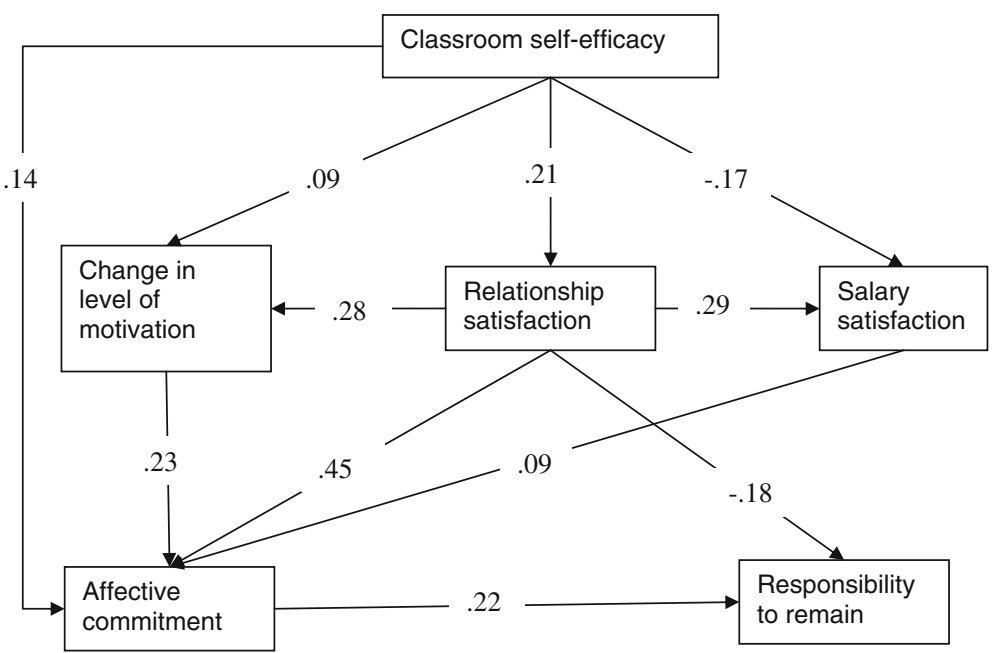

Fig. 2 Final structural model representing only the significant standardised relationships 
Table 4 Significant direct, indirect and total effects between the factors

\begin{tabular}{|c|c|c|c|}
\hline Factors & Direct & Indirect & Total \\
\hline Classroom self-efficacy $\rightarrow$ change in level of motivation & $0.20 * *$ & $0.13 * *$ & $0.33 * *$ \\
\hline Classroom self-efficacy $\rightarrow$ relationship satisfaction & $0.18 * *$ & - & $0.18^{* *}$ \\
\hline Classroom self-efficacy $\rightarrow$ salary satisfaction & $-0.20 * *$ & $0.07 * *$ & $-0.13 * *$ \\
\hline Classroom self-efficacy $\rightarrow$ affective occupational commitment & $0.14 * *$ & $0.12 * *$ & $0.26 * *$ \\
\hline Classroom self-efficacy $\rightarrow$ responsibility to remain in teaching & & $0.02 *$ & $0.02 *$ \\
\hline Change in level of motivation $\rightarrow$ affective occupational commitment & $0.11 * *$ & & $0.11 * *$ \\
\hline Change in level of motivation $\rightarrow$ responsibility to remain in teaching & & $0.02 * *$ & $0.02 * *$ \\
\hline Relationship satisfaction $\rightarrow$ change in level of motivation & $0.69 * *$ & & $0.69 * *$ \\
\hline Relationship satisfaction $\rightarrow$ affective occupational commitment & $0.51 * *$ & $0.10 * *$ & $0.61 * *$ \\
\hline Relationship satisfaction $\rightarrow$ responsibility to remain in teaching & $-0.18 * *$ & $0.12 * *$ & $-0.06^{*}$ \\
\hline Relationship satisfaction $\rightarrow$ salary satisfaction & $0.37 * *$ & & $0.37 * *$ \\
\hline Salary satisfaction $\rightarrow$ affective occupational commitment & $0.08 * *$ & & $0.08 * *$ \\
\hline Salary satisfaction $\rightarrow$ responsibility to remain in teaching & & $0.02 * *$ & $0.02 * *$ \\
\hline affective occupational commitment $\rightarrow$ responsibility to remain in teaching & $0.20 * *$ & & $0.20 * *$ \\
\hline
\end{tabular}

$* p<0.05 ; * * p<0.01$

this teacher is with his/her salary and received fringe benefits and that positive relationships may reduce teachers' feelings of pressure to remain in teaching. Lastly, the hypothesised relationship between teachers' salary satisfaction and their responsibility to remain in teaching was not significant and therefore removed from the model.

Considering the indirect effects, teachers' relationship satisfaction has a large influence as well. Teachers' relationship satisfaction reduces the negative effect of teachers' classroom self-efficacy on teachers' salary satisfaction $(\beta=0.07)$. This means that although a teacher's satisfaction with his/her salary may decrease when this teacher's classroom self-efficacy increases, it will decrease less when the teacher is, at the same time, satisfied with his/her relationships at work. Furthermore, the effect of teachers' classroom self-efficacy on teachers' affective occupational commitment was expected to be mediated by teachers' change in their level of motivation. Such indirect effect was indeed present $(\beta=0.02)$, yet the indirect effect mediated by teachers' relationship satisfaction was much larger $(\beta=0.11)$.

In addition to testing an overall model, it was explored whether the relationships between the indicators of teachers' sense of their professional identity were related to teachers' level of experience. The fit of the model was tested with the data from the 265 novice teachers, 341 experienced teachers and 603 senior teachers that had participated in this study. Using multiple-group SEM and a $\chi^{2}$ difference test, a fully unconstrained model was compared with an invariance model where the parameters were fixed for all three groups according to the findings as presented in the final model in Fig. 2.

Firstly, the invariance model was investigated. This resulted in a significant and wellfitting model. The results of the models tested are presented in Table 5. Next, the parameters of all groups were set free. The $\chi^{2}$ difference test showed that the change of $\chi^{2}$ between the invariance model and the unconstrained model compared with the change in the degrees of freedom between these models was not significant, meaning the invariance model and the unconstrained model do not significantly differ. Thus, the parameters do not differ across the groups (Kline 2005). 
Table 5 Goodness of fit indices for the compared models

\begin{tabular}{lrrrrrrrc}
\hline Model & $d f$ & \multicolumn{1}{c}{$\chi^{2}$} & \multicolumn{1}{c}{$p$} & RMSEA & CFI & NNFI & ddf & $\chi^{2}$ difference \\
\hline Total group model & 4 & 9.55 & 0.05 & 0.03 & 0.99 & 0.98 & - & - \\
Invariance model & 45 & 44.61 & 0.49 & 0.00 & 1.00 & 1.00 & - & \multicolumn{1}{c}{-} \\
Unconstrained model & 12 & 19.29 & 0.08 & 0.04 & 0.99 & 0.97 & 33 & 25.32 \\
Beginner model & 15 & 24.21 & 0.06 & 0.04 & 0.99 & 0.97 & 3 & 5.08 \\
\hline
\end{tabular}

\section{Discussion}

The primary aim of this study was to investigate the relationships between the indicators of teachers' sense of their professional identity: teachers' self-efficacy, job satisfaction, occupational commitment and the change in teachers' level of motivation. Based on the literature, a model was proposed and tested empirically. Using the data of 1,214 secondary school teachers, a final model with satisfactory fit indices incorporating all indicators was constructed.

Teachers' sense of their professional identity concerns teachers' perceptions of themselves as teachers based on their interpretations of the context in which they function and their interaction with this context (Kelchtermans 2009). This interaction with and perception of the context becomes apparent in the importance of a teacher's relationship with others. As became clear in this study, teachers' relationship satisfaction is a crucial indicator in the relationships between the other indicators of teachers' sense of their professional identity. Thus, the extent to which teachers are satisfied with their colleagues, the support they receive and the extent to which they feel competent in dealing with school administrators influence teachers' ratings of the other indicators. Rots et al. (2011) believe, based on their qualitative study, that more attention should be paid to such aspects in teacher education.

The importance of teachers' classroom self-efficacy and teachers' relationship satisfaction suggests that affecting a teacher's sense of professional identity would be possible by influencing these indicators as they influence, in their turn, the other indicators. Relationship satisfaction could be strengthened by providing or enhancing a supportive environment, making sure that teachers feel they are listened to by the school board and developing a strong feeling of relatedness between team members. Strengthening these aspects will increase teachers' classroom self-efficacy as well (e.g. Ashton and Webb 1986). Comprehensive induction arrangements incorporate such aspects, thus attending to many of the beginning teachers' needs (e.g. Helms-Lorenz et al. in press). For more experienced teachers, solutions might be sought in programmes to strengthen their relationship satisfaction as well.

Another factor which has been found to influence teachers' relationship satisfaction is the leadership style of a teacher's superior (Bogler 2001; Nguni et al. 2006). Bogler (2001) concluded that a transformational leadership style (which includes intellectually stimulating their teachers and having charisma and a clear vision) contributes positively to, what is called here, teachers' relationship satisfaction. A transactional leadership style (which includes giving contingent reward and management by exception, active as well as passive), on the other hand, contributes negatively to teachers' relationship satisfaction (Bogler 2001). As teachers' relationship satisfaction is an important indicator which influences the other indicators of teachers' sense of their professional identity, principals should employ a transformational leadership style. 
The second aim of this study was to explore whether the relationships between the indicators were related to teachers' level of experience. The results revealed that the parameter estimates for the overall group fitted the three groups-composed of novice, experienced and senior teachers-well and did not significantly differ across the three groups.

Beauchamp and Thomas (2009) have mentioned that the comparison of studies investigating the stability and/or dynamics of teachers' professional identity is difficult due to the different terms being used by researchers to refer to the 'shifting and shaping'as Beauchamp and Thomas call these processes - of a professional identity. Examples of such different terms are: the 'development' of identity (Olsen 2008), the 'construction' of identity (Coldron and Smith 1999) and the 'shaping' of an identity (Flores and Day 2006). Although different terms are used when referring to the stability and/or dynamics of teachers' professional identity, the core question of research on this subject is similar: does a teacher's professional identity change during the course of his/her career?

In this study, the relationships between the indicators of teachers' sense of their professional identity were found to be similar for novice, experienced and senior teachers. This similarity is in line with findings of Canrinus et al. (in press). Author et al. found that teachers, who differed from each other in their professional identity profile, did not significantly differ in their level of experience. Nevertheless, we assume that our model is dynamic. Although the model may be similar for the three experience groups, the strength of the indicators may vary. A teacher may have an off day, for instance, and feel less confident and competent or less satisfied. However, due to the cross-sectional design of this study, we cannot confirm or deny the stability or flexibility of teachers' professional identity. Furthermore, the presented results are based on exploratory research. The findings remain tentative until this study has been confirmed by other studies. Further and longitudinal research remains necessary to investigate the stability of the presented model more in depth and through a more development-oriented lens.

We should also remark that although the teachers who participated in this study are a fairly accurate representation of the population of Dutch teachers working in secondary education (Dutch Ministry of Education, Culture and Science, 2007), information about the teachers who did not respond is very limited. If teachers did not want to participate, they were asked to reply to the invitation e-mail, stating their reason for not participating, their age, gender, subject and their total years of experience in teaching. Unfortunately, too few teachers responded to this query for us to be able to accurately describe the characteristics of the non-respondents. The teachers who did respond replied that heavy workload and the consequent lack of time for surveys was their reason for not participating.

Although the findings have their limitations, they offer opportunities for further research which combines recent topics. A possibility for expanding the present study in future research lies in the investigation of teachers' emotions. The influence of emotion in teaching has gained attention the last two decades (see for a review Sutton and Wheatley 2003). Kelchtermans (2009) and Nias (1996) have mentioned emotions, for instance in the form of teachers' job satisfaction, as part of teachers' identity, based on their qualitative data. Likewise, using an ethnographical approach, Zembylas (2004, 2005) has linked teachers' emotions to teachers' professional identity. It would be contributing to the further understanding of the process of interaction between teachers and their context when further research relates teachers' emotions to teachers' professional identity on a larger scale. This could be done, for instance, by investigating more closely how emotions are related to - or incorporated within - the specific indicators of teachers' sense of their professional identity presented here. 
Finally, the presented model is relevant for other professionals' sense of their professional identity as well. The relevant indicators (job satisfaction, self-efficacy, occupational commitment and change in level of motivation) are constructs that play an important role in research on teachers' behaviour (cf. Ashton and Webb 1986; Firestone 1996) and, moreover, play a role in more general research on occupational psychology (cf. Blau and Holladay 2006; Judge et al. 2005). Furthermore, except for the occupationspecific items in the self-efficacy scale, the items used in the survey can easily be rephrased or directly distributed to other professionals (Irving et al. 1997).

Open Access This article is distributed under the terms of the Creative Commons Attribution Noncommercial License which permits any noncommercial use, distribution, and reproduction in any medium, provided the original author(s) and source are credited.

\section{References}

Ashton, P. T., \& Webb, R. B. (1986). Making a difference: Teachers' sense of efficacy and student achievement. New York: Longman.

Bandura, A. (1977). Self-efficacy: Toward a unifying theory of behavioral change. Psychological Review, 84, $191-215$.

Bandura, A. (1993). Perceived self-efficacy in cognitive development and functioning. Educational Psychologist, 28, 117-148.

Beauchamp, C., \& Thomas, L. (2009). Understanding teacher identity: An overview of issues in the literature and implications for teacher education. Cambridge Journal of Education, 39, 175-189.

Beijaard, D., Meijer, P. C., \& Verloop, N. (2004). Reconsidering research on teachers' professional identity. Teaching and Teacher Education, 20, 107-128.

Blau, G., \& Holladay, E. B. (2006). Testing the discriminant validity of a four-dimensional occupational commitment measure. Journal of Occupational and Organizational Psychology, 79, 691-704.

Bogler, R. (2001). The influence of leadership style on teacher job satisfaction. Educatonal Administration Quarterly, 37, 662-683.

Bogler, R., \& Somech, A. (2004). Influence of teacher empowerment on teachers' organizational commitment, professional commitment and organizational citizenship behavior in schools. Teaching and Teacher Education, 20, 277-289.

Cameron, J., \& Pierce, W. D. (1994). Reinforcement, reward, and intrinsic motivation: A meta-analysis. Review of Educational Research, 64, 363-423.

Canrinus, E. T., Helms-Lorenz, M., Beijaard, D., Buitink, J., \& Hofman, W. H. A. (in press). Profiling teachers' sense of their professional identity. Educational Studies. First published on: 20 January 2011 (iFirst).

Caprara, G. V., Barbaranelli, C., Steca, P., \& Malone, P. S. (2006). Teachers' self-efficacy beliefs as determinants of job satisfaction and students' academic achievement: A study at the school level. Journal of School Psychology, 44, 473-490.

Chan, W. Y., Lau, S., Nie, Y., Lim, S., \& Hogan, D. (2008). Organizational and personal predictors of teacher commitment: The mediating role of teacher efficacy and identification with school. American Educational Research Journal, 45, 597-630.

Ciani, K. D., Summers, J. J., \& Easter, M. A. (2008). A "top-down" analysis of high school teacher motivation. Contemporary Educational Psychology, 33, 533-560.

Coldron, J., \& Smith, R. (1999). Active location in teachers' construction of their professional identities. Journal of Curriculum Studies, 31, 711-726.

Cooper-Hakim, A., \& Viswesvaran, C. (2005). The construct of work commitment: Testing an integrative framework. Psychological Bulletin, 131, 241-259.

Davis, J., \& Wilson, S. M. (2000). Principals' efforts to empower teachers: Effects on teacher motivation and job satisfaction and stress. The Clearing House, 73, 349-353.

Day, C. (2002). School reform and transitions in teacher professionalism and identity. International Journal of Educational Research, 37, 677-692. 
Day, C., Stobart, G., Sammons, P., Kington, A., Gu, Q., Smees, R., et al. (2006). Variations in teachers' work, lives and effectiveness. Final report for the VITAE Project, DfES.

De la Torre Cruz, M., \& Casanova Arias, P. F. (2007). Comparative analysis of expectancies of efficacy in inservice and prospective teachers. Teaching and Teacher Education, 23, 641-652.

Dobrow, S. R., \& Higgins, M. C. (2005). Developmental networks and professional identity: A longitudinal study. Career Development International, 10, 567-583.

Firestone, W. A. (1996). Images of teaching and proposals for reform: A comparison of ideas from cognitive and organizational research. Educational Administration Quarterly, 32, 209-235.

Firestone, W. A., \& Pennell, J. R. (1993). Teacher commitment, working conditions, and differential incentive policies. Review of Educational Research, 63, 489-525.

Flores, M. A., \& Day, C. (2006). Contexts which shape and reshape new teachers' identities: A multiperspective study. Teaching and Teacher Education, 22, 219-232.

Friedman, I. A., \& Kass, E. (2002). Teacher self-efficacy: A classroom-organization conceptualization. Teaching and Teacher Education, 18, 675-686.

Guay, F., Ratell, C. F., Roy, A., \& Litalien, D. (2010). Academic self-concept, autonomous academic motivation, and academic achievement: Mediating and additive effects. Learning and Individual Differences, 20, 644-653.

Hackman, J. R., \& Oldham, G. R. (1976). Motivation through the design of work: Test of a theory. Organizational Behavior and Human Performance, 16, 250-279.

Hamman, D., Gosselin, K. Romano, J., \& Bunuan, R. (2010). Using possible-selves theory to understand the identity development of new teachers. Teaching and Teacher Education, 26, 1349-1361.

Helms-Lorenz, M., Slof, B., Vermue, C. E., \& Canrinus, E, T. (in press). Beginning teachers' self-efficacy and stress and the supposed effects of induction arrangements. Educational Studies.

Ibarra, H. (1999). Provisional selves: Experimenting with image and identity in professional adaptation. Administrative Science Quarterly, 44, 764-791.

Ingersoll, R. M., \& Smith, T. M. (2004). Do teacher induction and mentoring matter? NASSP Bulletin, 88, $28-40$.

Irving, P. G., Coleman, D. F., \& Cooper, C. L. (1997). Further assessments of a three-component model of occupational commitment: Generalizability and differences across occupations. Journal of Applied Psychology, 82, 444-452.

Judge, T. A., Bono, J. E., Erez, A., \& Locke, E. A. (2005). Core self-evaluations and job and life satisfaction: The role of self-concordance and goal attainment. Journal of Applied Psychology, 90, 257-268.

Kelchtermans, G. (2005). Teachers' emotions in educational reforms: Self-understanding, vulnerable commitment and micropolitical literacy. Teaching and Teacher Education, 21, 995-1006.

Kelchtermans, G. (2009). Who I am in how I teach is the message: Self-understanding, vulnerability and reflection. Teachers and Teaching, 15, 257-272.

Kline, R. B. (2005). Principles and practice of structural equation modeling. New York: The Guilford.

Landsman, M. J. (2001). Commitment in public child welfare. The Social Service Review, 75, 386-419.

Latham, G. P., \& Pinder, C. C. (2005). Work motivation theory and research at the dawn of the twenty-first century. Annual Review of Psychology, 56, 485-516.

Lee, K., Carswell, J. J., \& Allen, N. J. (2000). A meta-analytic review of occupational commitment: Relations with person- and work-related variables. Journal of Applied Psychology, 85, 799-811.

Liu, X. S., \& Ramsey, J. (2008). Teachers' job satisfaction: Analyses of the teacher follow-up survey in the United States for 2000-2001. Teaching and Teacher Education, 24, 1173-1184.

Martin, A. J., \& Dowson, M. (2009). Interpersonal relationships, motivation, engagement, and achievement: Yields for theory, current issues and educational practice. Review of Educational Research, 79, 327-365.

Maslow, A. H. (1943). A theory of human motivation. Psychological Review, 50, 370-396.

Mather, L., McEwen, C. A., \& Maiman, R. J. (2001). Divorce lawyers at work. Varieties of professionalism in practice. Oxford: Oxford University Press.

McAulay, B. J., Zeitz, G., \& Blau, G. (2006). Testing a "push-pull” theory of work commitment among organizational professionals. The Social Science Journal, 43, 571-596.

McKinney, P. A. (2000). A study to assess the relationships among student achievement, teacher motivation, and incentive pay. Unpublished doctoral dissertation, University of Blacksburg, Virginia.

Meyer, J. P., Allen, N. J., \& Smith, C. A. (1993). Commitment to organizations and occupations: Extension and test of a three-component conceptualization. Journal of Applied Psychology, 78, 538-551.

Moore, M., \& Hofman, J. E. (1988). Professional identity in institutions of higher learning in Israel. Higher Education, 17, 69-79.

Nguni, S., Sleegers, P., \& Denessen, E. (2006). Commitment, and organizational citizenship behaviour in primary schools: The Tanzanian case. School Effectiveness and School Improvement, 17, 145177. 
Nias, J. (1996). Thinking about feeling: The emotions in teaching. Cambridge Journal of Education, 26, 293-306.

Nias, J. (1997). Would schools improve if teachers cared less? Education, 3-13(25), 11-22.

Olsen, B. (2008). Teaching what they learn, learning what they live. Boulder: Paradigm.

Pratt, M. G., Rockmann, K. W., \& Kaufmann, J. (2006). Constructing professional identity: The role of work and identity learning cycles in the customization of identity among medical residents. Academy of Management Journal, 49, 235-262.

Puurula, A., \& Löfström, E. (2003). Development of professional identity in SMEs. Paper presented at the Annual Meeting of the American Educational Research Association, Chicago, IL.

Rots, I., Aelterman, A., Vlerick, P., \& Vermeulen, K. (2007). Teacher education, graduates' teaching commitment and entrance into the teaching profession. Teaching and Teacher Education, 23, 543-556.

Rots, I., Kelchtermans, G., \& Aelterman, A. (2011). Changes in student teachers' job motivation: A qualitative study. Paper presented at the 2011 Annual meeting of the American Educational Research Association (AERA), April 8-12, New Orleans, LA, USA.

Ryan, R. M., \& Deci, E. L. (2000). Intrinsic and extrinsic motivations: Classic definitions and new directions. Contemporary Educational Psychology, 25, 54-67.

Schepers, C., De Gieter, S., Pepermans, R., Du Bois, C., Caers, R., \& Jegers, M. (2005). How are employees of the nonprofit sector motivated? A research need. Nonprofit Management \& Leadership, 16, 191-208.

Sinclair, C., Dowson, M., \& McInerney, D. M. (2006). Motivations to teach: Psychometric perspectives across the first semester of teacher education. Teachers College Record, 108, 1132-1154.

Sugrue, C. (2005). Revisiting teaching archetypes. In D. Bijaard, P. C. Meijer, G. Morine-Dershimer, \& H. Tillema (Eds.), Teacher professional development in changing conditions. Dordrecht: Springer.

Super, D. E., \& Hall, D. T. (1978). Career development: Exploration and planning. Annual Review of Psychology, 29, 233-272.

Sutton, R. E., \& Wheatley, K. F. (2003). Teachers' emotions and teaching: A review of the literature and directions for future research. Educational Psychology Review, 15, 327-358.

Toh, K.-A., Ho, B.-T., Riley, J. P., \& Hoh, Y.-K. (2006). Meeting the highly qualified teachers challenge. Educational Research for Policy and Practice, 5, 187-194.

Tschannen-Moran, M., Hoy, A., \& Hoy, W. (1998). Teacher efficacy: It's meaning and measure. Review of Educational Research, 68, 202-248.

Van der Ploeg, J. D., \& Scholte, E. M. (2003). Arbeidssatisfactie onder leraren [Job satisfaction among teachers]. Pedagogiek, 23, 276-290.

Vroom, V. H. (1964). Work and motivation. New York: Wiley.

Watt, H. M. G., \& Richardson, P. W. (2008). Motivations, perceptions, and aspirations concerning teaching as a career for different types of beginning teachers. Learning and Instruction, 18, 408-428.

Weiner, B. (1972). Attribution theory, achievement motivation, and the educational process. Review of Educational Research, 42, 203-215.

Wentzel, K. R. (1999). Social-motivational processes and interpersonal relationships: Implications for understanding motivation at school. Journal of Education Psychology, 91, 76-97.

Wigfield, A., \& Eccles, J. S. (2000). Expectancy-value theory of achievement motivation. Contemporary Educational Psychology, 25, 68-81.

Zembylas, M. (2004). The emotional characteristics of teaching: An ethnographic study of one teacher. Teaching and Teacher Education, 20, 185-201.

Zembylas, M. (2005). Discursive practices, genealogies, and emotional rules: A poststructuralist view on emotion and identity in teaching. Teaching and Teacher Education, 21, 935-948.

Esther Canrinus is a post doc researcher at the University of Groningen. Her research focuses on teachers' professional identity and teachers' motivation for teaching. She is, furthermore, working on a project investigating the effect of various types of teacher training on multiple teacher outcomes such as teacher stress and teaching behaviors. Her research interest includes teachers' professional identity, professional development, motivation, and occupational psychology.

Michelle Helms-Lorenz is assistant professor at the University of Groningen Her current efforts are focussed on the enhancement of the professional development of (student- and beginning-) teachers and the effects on pupil achievement. Her research interest includes: the well-being of beginning and pre-service teachers and effective interventions to promote their professional growth and retention. 
Douwe Beijaard is professor of professional learning in the domain of teaching and teacher education at Eindhoven University of Technology. He was and is (executive) member of editorial boards of several scientific journals. His current research addresses the professional identity, quality and development of (beginning) teachers.

Jaap Buitink is associate professor at the University of Groningen. His main interests are school based teacher education, professional development of beginning teachers, and learning at the workplace. He has published in different journals and chapter books.

Adriaan Hofman is professor of Education at the University of Groningen in the Netherlands as well as Professor of Education Studies at Erasmus University Rotterdam in the Netherlands. He specializes in school and teacher effectiveness, higher education, education in developing countries, research methods, urban education, and learning cities. 